DOI: 10.46340/eppd.2020.7.6.41

\title{
Ivanna Hranina
}

ORCID ID: https://orcid.org/0000-0002-3626-269X

National University "Odessa Law Academy», Ukraine

\section{NOTARIAL CERTIFICATION OF THE WILL AS A GUARANTEE OF ENSURING THE RIGHTS OF THE LEGATOR}

\author{
Іванна Граніна \\ Національний університет "Одеська юридична академія», Україна

\section{НОТАРІАЛЬНЕ ПОСВІДЧЕННЯ ЗАПОВІТУ \\ ЯК ГАРАНТІЯ ЗАБЕЗПЕЧЕННЯ ДОДЕРЖАННЯ ПРАВ ЗАПОВІДАЧА}

The article analyzes the peculiarities of the will, in particular its design, which would not violate the rights of the legator. It is concluded that the notarization of the will is a guarantee of real enforcement of the legator's rights. Therefore, the function of the notary to verify the accuracy of the wording of the legator in the will is important and responsible. Therefore, the text of the will may not contain inaccuracies in the wording, as this may lead to misreading, complicating or preventing the implementation of the provisions of such a will. As the will is implemented only after the death of the legator, there is no real opportunity to clarify certain provisions of the will. The need in practice is determined to clearly distinguish between cases that result to the invalidity of the will (such as lack of notarization) and errors that can not lead to the invalidity of the will (such as lack of indication of place and time of the will), but should be corrected (due to the fact that such a possibility exists after the death of the testator).

Keywords: inheritance, will, legator, heir, notary, notarization of the will.

Постановка проблеми. Важливе значення для дійсності того чи іншого виду правочину має його оформлення (форма). Законодавець встановлює загальні вимоги, додержання яких є необхідною передумовою для чинності правочину. Зокрема, ч. 4 ст. 203 передбачає необхідність вчинення правочинів у формі, встановленій законом. Недодержання такої вимоги є підставою для визнання правочину недійсним (ст. 215 ЦК України). Отже, враховуючи що заповіт є правочином, і відповідно до законодавства має вчинятися у письмовій формі з обов'язковим нотаріальним посвідченням, неналежне оформлення заповіту може ускладнити і без того складну процедуру виконання заповіту.

Зокрема, основними вимогами, які висуваються до форми заповіту законодавцем, $є:$ укладення його в письмовій формі (із зазначенням місця та часу його складення), особисте підписання заповідачем (за умови відсутності такої можливості особа у зв'язку з хворобою або фізичною вадою може доручити у їі присутності підписати текст правочину (в даному випадку заповіту) іншій особі), обов'язкове посвідчення нотаріусом або іншими посадовими, службовими особами (які визначені у статтях 1251-1252 ЦК України ${ }^{1}$. Також важливою $€$ i вимога державної реєстрації заповіту у Спадковому реєстрі, що передбачено Постановою КМУ².

Для того, щоб виконавець заповіту послідовно, у повній відповідності з законом здійснював усі дії з виконання заповіту, необхідне, перш за все, правильне оформлення основного акту, на якому грунтуються повноваження виконавця заповіту - заповідального розпорядження (заповіту). А вже потім, пересвідчившись у дотриманні вимог законодавства щодо форми заповіту, нотаріус

\footnotetext{
${ }^{1}$ Цивільний кодекс Украӥни, 2003 (Верховна Рада України). Офіційний веб-сайт Верховної Ради Украӥни <https://zakon.rada.gov.ua/laws/show/435-15> (2020, листопад, 25).

2 Про затвердження Порядку державної реєстрації заповітів і спадкових договорів у Спадковому реєстрі. Постанова Кабінету Міністрів України, 2011 (Верховна Рада України). Офіиійний веб-сайт Верховної Ради Украӥни <https://zakon.rada.gov.ua/laws/show/491-2011-\%D0\%BF\#Text> (2020, листопад, 25).
} 
відповідним чином посвідчує повноваження виконавця заповіту, надавши йому свідоцтво. Отже, однією з гарантій додержання прав заповідача $є$ нотаріальне посвідчення заповіту. Враховуючи кількість питань, які виникають на практиці, теоретичне вивчення зазначених питань $€$ актуальним та необхідним для якісного забезпечення захисту прав заповідача.

Аналіз основних досліджень і публікацій. Окремі аспекти спадкування за заповітом та його виконання були предметом наукових досліджень Л.В. Козловської, О.С. Кухарєвого, С.В. Мазуренко, Р.А. Майданика, Є.О. Рябоконя, С.В. Фесенко, І.Я. Федорич, С.І. Фурси, С.Я. Фурси, Л.В. Шевчук, Є.О. Харитонова та ін. Разом з тим, постійне напрацювання судової практики, оновлення законодавства, соціально-економічні умови існування зумовлюють необхідність звернення до дослідження інституту заповіту в сучасному цивільному праві України, зокрема, як інструменту забезпечення права заповідача на вільне волевиявлення щодо долі свого майна після смерті.

Метою статті $\epsilon$ аналіз українського законодавства та судової практики щодо ролі нотаріуса при посвідченні заповіту, та самого факту нотаріального посвідчення як елементу забезпечення додержання прав заповідача.

Виклад основного матеріалу. Згідно ст. 1233 ЦК України заповіт - це особисте розпорядження фізичної особи на випадок своєї смерті. Законодавець звертає увагу на те, що заповідачем може бути фізична особа з повною цивільною дієздатністю, тобто особа, яка досягла повноліття. Однак у разі реєстрації шлюбу фізичної особи, яка не досягла повноліття, вона набуває повної цивільної дієздатності з моменту реєстрації шлюбу. Повна цивільна дієздатність може бути надана фізичній особі, яка досягла 16 років і працює за трудовим договором, а також неповнолітній особі, яка записана матір'ю або батьком дитини. Отже, заповідальна правоздатність формально визнається за кожною фізичною особою, однак, на відміну від інших елементів правоздатності фізичної особи, вона фактично звужена суто особистим характером заповіту як правочину, який не можна вчинити через представника. У зв'язку з цим в літературі зазначається, що право заповідати з'являється у фізичної особи з виникненням у неї права ухвалення рішення про здійснення заповіту чи виникненням у неї заповідальної дієздатності, яка виникає на момент повноліття. ${ }^{1}$

Аналіз судової практики дає висновок стверджувати, що правильне встановлення цивільної дієздатності особи має провідне значення для чинності заповіту. Для чого потрібно документально обгрунтувати факт обмеженої цивільної дієздатності або взагалі недієздатності, оскільки правові наслідки такого правочину дуже суттєві для визначення «реальних» спадкоємців.

Проте, звертаючись до грунтовного тлумачення права на заповіт, необхідно зазначити, що це питання не має однозначного вирішення щодо посвідчення заповітів обмежено дієздатних осіб. Зокрема, існує правова позиція науковців (наприклад, це М.Ю. Барщевський ${ }^{2}$, В.К. Дронников ${ }^{3}$, Т.Д. Чепіга ${ }^{4}$ ), які на відміну від інших авторів передбачають можливість за частково дієздатними особами заповідати своє майно з таких підстав: особа, що зловживає спиртними напоями або наркотичними засобами, не позбавляється законом повної громадянської дієздатності, а лише обмежується у ній; метою призначення піклувальника $\epsilon$ недопущення громадянином такого використання свого майна, що йтиме на шкоду йому самому, його сім'ї; заповіт здійснюється лише після смерті заповідача і не може бути використаним для продовження зловживання спиртними напоями та наркотичними засобами.

Тобто, досить цікава аргументація зробленої пропозиції має під собою грунт, який можна було б вважати логічним і в дусі сучасної демократизації суспільних відносин.

Можна додати, що законодавець, обмежуючи громадянина в праві здійснювати значимі цивільно-правові правочини, мав на увазі також легку можливість шахраїв обдурити і вплинути на обмежено дієздатну особу при укладенні правочини. Але заповіт - це односторонній правочин, за яким заповідач передає все своє майно або його частку та може визначати ті умови, за якими спадкоємці вправі його прийняти. Отже, при посвідченні заповіту вплив інших осіб на заповідача має бути обмеженим.

3 позицій практики слід суттєво переглянути таку можливість, оскільки обмежено дієздатні особи, які зловживають спиртними напоями та наркотичними засобами стають легкою здобиччю

\footnotetext{
${ }^{1}$ Писарєва, Е. (2009). Заповіт як підстава виникненняспадкових відносин: деякі аспекти правового регулювання. Вісник академї̈ управління МВС, 3, 106.

${ }^{2}$ Барщевский, М. Ю. (1989). Если открылось наследство. Москва: Юридическая литература, 68.

3 Дронников, В. К. (1974). Наследственное право Украинской ССР. Київ: Вища школа, 72.

4 Чепига, Т. Д. (1965). К вопросу о праве завещать. Весник МГУ, 2, 51.
} 
шахраїв, можуть за одну «необхідну» для них дозу алкоголю або наркотику винести з дому будь-яку річ тощо, а тому доцільно не надавати права обмежено дієздатним особам посвідчувати заповіти. Вже існує доволі багато громадян, які підписували договори щодо відчуження квартир і які опинилися «на вулиці», а тому потрібно дбати про інтереси осіб, які надають допомогу обмежено дієздатним особам, та їх родичів.

Кожна людина, незалежно від того, чи є вона громадянином України, іноземцем, чи особою без громадянства, вправі посвідчити від свого імені заповіт на території України.

Заповіт - це односторонній правочин, який повинен бути укладений у письмовій формі із зазначенням місця і часу його посвідчення, підписаний особисто заповідачем і посвідчений нотаріусом або іншими службовими особами, уповноваженими на це.

При цьому слід розуміти, що відсутність однієї з умов може стати причиною визнання заповіту недійсним. Однак, проти кого буде спрямована дія закону. Стаття закону перераховує комплекс умов, які співіснують, але можуть поглинатися одним суттєвим аспектом. Так, недійсність заповіту може виникнути лише в тому разі, коли особа не звернулася до нотаріуса й на складеному заповіті відсутні будь-які ознаки нотаріального його посвідчення. Йдеться про випадок, коли після смерті особи заповіт буде знайдено в тому приміщенні, де знаходився спадкодавець.

Коли ж заповіт нотаріально посвідчений і в ньому не зазначені місце й час його укладення, то це необхідно відносити до помилки нотаріуса, але помилки, яка може бути виправлена, оскільки нотаріус зобов'язаний реєструвати вчинювані нотаріальні дії у відповідних реєстрах нотаріальних дій, а відомості про посвідчення заповіту мають вноситися також до комп'ютерної бази даних Спадкового реєстру ${ }^{1}$.

Якщо в заповіті відсутня дата його посвідчення, то ця обставина має правове значення, коли в державному нотаріальному архіві існують і заповіти, складені від імені спадкодавця або стосовно особи є відомості про ії недієздатність під час посвідчення заповіту, а при відсутності такої інформації немає підстав для визнання такого заповіту недійсним з причин відсутності дати.

Якщо ж на заповіті відсутній особистий підпис заповідача, то такий заповіт, на наш погляд, має визнаватися недійсним. Це свідчить про помилку як нотаріуса, так і особи, оскільки відомості про необхідність підписання документів $\epsilon$ загальновідомими i не пов'язуються із спеціальною юридичною компетенцією.

Вимагаючи від заповідача додержання обов'язкової процедури нотаріального посвідчення заповіту, законодавець одночасно вживає заходів для охорони його прав, оскільки при цьому покладає на нотаріуса обов'язок чітко дотримуватись вимог закону. Така правова функція нотаріального процесу передбачена саме для юридичне необізнаних осіб.

Таким чином, можна зробити висновок, що в силу ролі нотаріуса в правовій системі України та його компетенції, саме на нього покладається обов'язок додержуватися вимог закону і контролювати дії особи від можливих процесуальних помилок. Це положення випливає з процесуального порядку здійснення нотаріального процесу, тобто в силу ст. ст. 5,6 Закону України «Про нотаріат» ${ }^{2}$ нотаріус зобов'язаний виконувати обов'язки згідно із законом. Отже, можна зробити висновок про те, що в ст. 1247 ЦК України достатньо залишити лише одну умову, що заповіт підлягає обов'язковому нотаріальному посвідченню. При цьому, всі інші вимоги, які стосуються змісту та вимог щодо оформлення заповіту можуть бути перенесені до Закону України «Про нотаріат». Це зауваження має підкреслити відмінність норм матеріального і процесуального характеру. Оскільки нотаріальний процес має певну форму, то й норми, що регламентують вимоги до форми, мають відноситись до процесуальних.

Нотаріус на прохання особи вправі записати заповіт з ії слів власноручно або за допомогою загальноприйнятих технічних засобів.

Звертаємо увагу, що законодавець передбачив право посвідчувати заповіт за бажанням заповідача при свідках. У населених пунктах, де немає нотаріусів, заповіти, крім секретного, посвідчують посадові, службові особи відповідного органу місцевого самоврядування. Також законодавець встановлює вичерпний перелік осіб, чиє посвідчення заповіту прирівнюється

\footnotetext{
${ }^{1}$ Положення про спадковий реєстр: Наказ Міністрерства юстиції Украӥни, 2011 (Верховна Рада України). Офіиійний веб-сайт Верховної Ради Украӥни <https://zakon.rada.gov.ua/laws/show/z0831-11\#Text> (2020, листопад, 25).

${ }^{2}$ Про нотаріат, 1993 (Верховна Рада України). Офіиійний веб-сайт Верховної Ради України

<https://zakon.rada.gov.ua/laws/show/3425-12\#Tеxt> (2020, листопад, 25).
} 
за правовим значенням до нотаріального (див. ст. 1252 ЦК України). Говорячи про заповіти, що прирівнюються за правовим значенням до нотаріально посвідчених, слід зауважити, що ці випадки слід розуміти як виняток із правила, а не саме правило, адже відповідні службові особи мають право посвідчити заповіт лише при наявності свідків, яких, відповідно до ст. 1255 ЦК України, повинні попереджувати про нерозголошення факту складання заповіту. При посвідченні заповітів службові особи, визначені в ст. 1252 ЦК України, повинні дотримуватися загальних вимог до форми заповіту, передбачених у ст. 1247 ЦК України ${ }^{1}$.

Крім того, юридичні знання у більшості перелічених у ст. ст. 1251, 1252 ЦК України осіб, що мають право за певних обставин посвідчити заповіт, важко назвати грунтовними. При цьому, процесуальний порядок набрання законної сили заповітом, посвідченим такими особами, також відрізняється від нотаріального посвідчення. Частини 6 ст. 40 Закону України «Про нотаріат» передбачає, що державний нотаріус державного нотаріального архіву зобов'язаний перевірити законність заповіту, що надійшов на зберігання, та залишити у себе отриманий ним примірник заповіту з повідомленням про це заповідача та посадової особи, яка посвідчила заповіт. У разі встановлення невідповідності заповіту законові державний нотаріус державного нотаріального архіву повідомляє про це заповідача і посадову особу, яка посвідчила заповіт.

Така процедура перегляду змісту заповіту дозволяє встановити наявність розбіжностей у змісті заповіту з вимогами закону, але, на наш погляд, такий процесуальний порядок не має під собою правового змісту, не відповідає загальноприйнятій компетенції нотаріальних органів тощо. В цьому випадку повинна мати місце лише констатація факту розбіжності заповіту із законом, оскільки, за загальним правилом, повноваженнями щодо визнання угод недійсними, в тому числі й заповіту як односторонньої угоди, наділений виключно суд. Тому пропонуємо розглядати дії завідуючого державним нотаріальним архівом лише як попередню перевірку юридичної компетентності заповідача та дій особи, яка посвідчила заповіт.

Якщо заповідач внаслідок фізичної вади (хвороби) або з будь-яких причин не може підписати особисто заповіт, за його дорученням та у його присутності і в присутності нотаріуса або посадової особи заповіт може бути підписаний іншим громадянином у відповідності з пунктом 16 Інструкції про порядок вчинення нотаріальних дій нотаріусами України. При цьому в посвідчувальному написі обов'язково зазначаються причини, через які заповідач не міг підписати заповіт власноручно. Заповіт не може підписати особа, на користь якої його зроблено.

Звертаємо увагу, що в такому випадку (відповідно до ст. 1253 ЦК України) посвідчення даного заповіту повинно відбуватися також в присутності не менш як двох свідків ${ }^{2}$.

На бажання заповідача нотаріус також може посвідчити заповіт при свідках, яких повинно бути не менше ніж два. У тексті заповіту зазначаються відомості про свідків, зокрема: прізвище, ім'я та по батькові кожного, дати їх народження, реквізити паспортів чи інших документів, на підставі яких встановлено особу свідка.

Свідки зобов'язані прочитати заповіт вголос та проставити на ньому підписи.

Свідками можуть бути лише особи з повною цивільною дієздатністю. Свідками, крім осіб, на користь яких складено заповіт, не можуть бути також члени сім’ї та близькі родичі спадкоємців за заповітом, особи, які не можуть прочитати або підписати заповіт, а також нотаріус.

У відповідності зі статтями 1234, 1254 ЦК України ${ }^{3}$ та статтями 56, 57 Закону України «Про нотаріат» ${ }^{4}$, заповіт може бути складено, змінено або скасовано лише особисто самим громадяниномзаповідачем. Вчинення заповіту через представника не допускається.

Позитивним, на нашу думку, $є$ те, що розголошувати відомості стосовно факту складення заповіту, його змісту, скасування або зміни до відкриття спадщини не мають права, окрім нотаріуса, також інші посадові особи, котрі посвідчують заповіт, та фізична особа, яка підписує заповіт замість заповідача.

\footnotetext{
${ }^{1}$ Цивільний кодекс України, 2003 (Верховна Рада України). Офіиійний веб-сайт Верховної Ради Украӥни <https://zakon.rada.gov.ua/laws/show/435-15> (2020, листопад, 25).

${ }^{2}$ Цивільний кодекс України, 2003 (Верховна Рада України). Офіиійний веб-сайт Верховної Ради України $<$ https://zakon.rada.gov.ua/laws/show/435-15> (2020, листопад, 25).

${ }^{3}$ Цивільний кодекс України, 2003 (Верховна Рада України). Офіиійний веб-сайт Верховної Ради Украӥни

$<$ https://zakon.rada.gov.ua/laws/show/435-15> (2020, листопад, 25).

${ }^{4}$ Про нотаріат, 1993 (Верховна Рада України). Офіиійний веб-сайт Верховної Ради України

<https://zakon.rada.gov.ua/laws/show/3425-12\#Tеxt> (2020, листопад, 25).
} 
Висноски. Основним призначенням заповіту є визначення спадкоємців на майно. Заповідач може обирати спадкоємців самостійно, незалежно від того, чи входять вони до кола спадкоємців за законом, і тих, які не входять до цього кола, інших учасників цивільних відносин. Якщо заповідач виявив бажання залишити конкретне майно конкретним особам, то він повинен чітко зазначити, яке саме майно кому конкретно він заповідає. За бажанням заповідача в тексті заповіту можна зазначати родинні відносини зі спадкоємцем.

Особливу увагу нотаріус зобов'язаний приділити викладенню волевиявлення заповідача, тобто перевірити, щоб заповіт не містив висловів, у яких були б протиріччя. В даному випадку необхідно пам'ятати, що текст заповіту не може містити неточності в формулюваннях, адже це може потягнути за собою різночитання, ускладнивши чи унеможлививши виконання положень такого заповіту.

Важливо також пам'ятати, що заповіт реалізується лише після смерті заповідача, а отже, відсутня реальна можливість уточнювати чи з'ясовувати певні положення заповіту. Саме тому заповіт повинен містити такі формулювання, щоб розпорядження заповідача не викликало непорозумінь чи суперечок після відкриття спадщини.

\section{References:}

1. Tsyvilnyj kodeks Ukrayiny, 2003 (Verkhovna Rada Ukrayiny) [Civil Code of Ukraine, 2003 (Verkhovna Rada of Ukraine)]. Ofitsiynyy sayt Verkhovnoyi Rady Ukrayiny [The official website of the Verkhovna Rada of Ukraine]. 〈https://zakon.rada.gov.ua/laws/show/435-15>, (2020, November, 25). [in Ukrainian].

2. Postanova Pro zatverdzhennia Poriadku derzhavnoi reiestratsii zapovitiv i spadkovykh dohovoriv u Spadkovomu reiestri, 2011 (Kabinetu Ministriv Ukrainy) [Resolution On approval of the Procedure for state registration of wills and inheritance agreements in the Inheritance Register, 2011 (Cabinet of Ministers of Ukraine)]. Ofitsiynyy sayt Verkhovnoyi Rady Ukrayiny [The official website of the Verkhovna Rada of Ukraine]. <https://zakon.rada.gov.ua/laws/show/491-2011-\%D0\%BF\#Text> (2020, November, 25). [in Ukrainian].

3. Pysarieva, E. (2009). Zapovit yak pidstava vynyknennia spadkovykh vidnosyn: deiaki aspekty pravovoho rehuliuvannia. [Testament as a basis for hereditary relations: some aspects of legal regulation]. Visnyk akademii upravlinnia MVS [Bulletin of the Academy of Management of the Ministry of Internal Affairs], 3, 104-113. [in Ukrainian].

4. Barshchevskij, M. Yu. (1989). Esli otkrylos nasledstvo [If the inheritance is opened]. Moscow: YUlit. [in Russian].

5. Dronnikov, V. K. (1974). Nasledstvennoe pravo Ukrainskoj SSR. [Heritage law of the Ukrainian SSR]. Kyiv: Vishcha shkola. [in Russian].

6. Chepiga, T. D. (1965). K voprosu o prave zaveshchat [On the question of the right to bequeath]. Vesnik MGU, 2, 50-55. [in Russian].

7. Nakaz Polozhennia pro spadkovyi reiestr, 2011 (Ministrerstvo yustytsii Ukrainy) [Order of Regulations on the hereditary register, 2011 (Ministry of Justice of Ukraine). Ofitsiynyy sayt Verkhovnoyi Rady Ukrayiny [The official website of the Verkhovna Rada of Ukraine] 〈https://zakon.rada.gov.ua/laws/show/z0831-11\#Text> (2020, November, 25). [in Ukrainian].

8. Zakon Ukrainy Pro notariat, 1993 (Verkhovna Rada Ukrayiny) [Law of Ukraine About the notary, 1993] Ofitsiynyy sayt Verkhovnoyi Rady Ukrayiny [The official website of the Verkhovna Rada of Ukraine]. <https://zakon.rada.gov.ua/laws/show/3425-12\#Text> (2020, November, 25). [in Ukrainian]. 